\title{
Genetic Variability, Correlation and Path coefficient Analysis for Yield and Yield Attributing Traits in Advanced Breeding Lines (ABLs) of Green Gram [Vigna radiata (L.)Wilczek] in $\mathbf{F}_{6}$ Generation
}

\author{
L. S. Abhisheka ${ }^{1}$ and Suma C. Mogali ${ }^{2}$ \\ ${ }^{1}$ Department of Genetics and Plant Breeding, ${ }^{2}$ AICRP on MULLaRP, Main Agricultural \\ Station, College of Agriculture, University of Agricultural Sciences, \\ Dharwad- 580005, Karnataka, India \\ *Corresponding author
}

\section{A B S T R A C T}

\begin{tabular}{l} 
K e y w o r d s \\
$\begin{array}{l}\text { Genetic variability, } \\
\text { correlation } \\
\text { coefficient, path } \\
\text { analysis, green } \\
\text { gram, advanced } \\
\text { breeding lines }\end{array}$ \\
\hline Article Info \\
$\begin{array}{l}\text { Accepted: } \\
\text { 14 May 2020 } \\
\text { Available Online: } \\
\text { 10 June 2020 }\end{array}$ \\
\hline
\end{tabular}

\section{Introduction}

Green gram [Vigna radiata (L.) Wilczek], also known as mungu, pachaipayaru, golden gram and green soy. It is from Indo-Burma region of Hindustan (Vavilov, 1926). Pulses are the major group of food crops that could play an important role in solving the problems $v i z$., food security and nutritional security and also block the environmental challenges. It will adds about 9-10 per cent to total food grain production and is an inexpensive source of plant derived proteins, minerals and vitamins.

In some part of the Middle East, it acts as a major ingredient in cuisines. The achievement of plant breeding programme depends on 
thorough knowledge of current genetic differences and degree of association between yield and its component characters is essential for developing high yielding genotypes in green gram. The information about direct and indirect effect of component yield characters on dependent character is also important for genetic improvement activities. Yield is a complex character and it is influenced by many component characters.

So absence of sufficient genetic variability in economically important measureable traits is considered to be one of the major barriers in yield improvement of green gram. Numerous tactics have been engaged up for enrichment of genetic variability in green gram but hybridization and induction of mutations are considered to be relatively promising to select appropriate variants from the segregating population (Kumar et al., 2013). Association studies are the most important technique, which explains the magnitude and scope of relationship exist among important plant traits and correlation study provides basic measure for selection. However the data it supplies on the nature of association is often inadequate (Sahu et al., 2015).

Path coefficient analysis is an effective quantitative technique, particularly designed to measure the interrelationship of different yield influencing characters and their indirect and direct effects on dependent character i.e., seed yield. Based on this technique yield influencing characters will be ranked and particular characters showing a given magnitude of correlation could be concentrated for further improvement of yield (Hemavathy et al., 2015). Heritability of a quantitative character measures the amount of similarity between the parental genotypes and the progenies and its magnitude directs the ability with which a genotype can be identified by its phenotypic countenance, whereas genetic advance assistances in exercising the essential selection pressure (Prasad and Prasad, 2013). Identification of better parents revealing high heritability and high genetic advance for several characters is a crucial prerequisite for any crop improvement programme (Bhutia et al., 2016). Above aspects are essential and valuable in crop improvement as they benefit plant breeders in identification of finest genotypes for qualitative and quantitative traits for variety and hybridization breeding programme. Keeping the above details in view, the present exploration was under taken to estimate genetic variability, heritability, genetic advance and association studies on yield and component traits in green gram.

\section{Materials and Methods}

The experiment was conducted during summer- 2019 at F- block, Experimental plot, AICRP on MULLaRP, Main Agricultural Research Station (MARS), College of Agriculture, University of Agricultural Sciences (UAS), Dharwad, Karnataka. The research site was located $15^{\circ} 12^{\prime} \mathrm{N}$ latitude and $75^{\circ} 07^{\prime}$ E longitudes with an altitude of $678 \mathrm{~m}$ above mean sea level. The experiment was carried out from $28^{\text {th }}$ January 2019 to $2^{\text {nd }}$ May 2019. For the study of genetic variability, Correlation and Path analysis for 110 advanced breeding lines derived from 14 crosses in $\mathrm{F}_{6}$ generation were used as experimental material. The experiment was conducted in augmented block design with nine parental check. Each row length of $4 \mathrm{~m}$ with plant to plant spacing $10 \mathrm{~cm}$ and row to row spacing $30 \mathrm{~cm}$ was maintained. Each advanced breeding lines was sown in three rows of four meter length in ordered to minimize the environmental effect on individual ABLs and each row was maintained with 40 plants. Regular agronomic practices were carried out to maintain healthy crop. 


\section{Recording of observations}

All the eleven important yield and yield influencing characters observations were recorded for randomly selected five plants from each advanced breeding line. The data on days to $50 \%$ flowering, days to maturity, plant height, primary branches per plant, number of clusters per plant, number of pods per cluster, number of pods per plant, pod length, number of seeds per pod, hundred seed weight and seed yield per plant were recorded.

These data computed to estimate Genotypic Coefficient of Variation (GCV) and Phenotypic Coefficient of Variation (PCV) using the formulae of Burton and De Vane (1953); Heritability by Lush (1949) and Hanson et al., (1956); Genetic Advance (GA) by Johnson et al., (1955); Correlation by Singh and Chaudhary (1977) and Path analysis was carried out from method devised by Dewey and Lu. (1959).

\section{Results and Discussion}

Analysis of variances for 110 advanced breeding lines derived from fourteen crosses ( $\mathrm{F}_{6}$ generation) revealed that, there is a significant difference existing between progenies/entries of each block with respect to all studied characters. The significant variation was observed for all the studied characters. The mean square values between 11 characters are presented in Table 1 .

\section{Performance of genotypes}

Days to 50\% flowering ranged from 40 to 46 days; plant height ranged between 18.33 to $43.66 \mathrm{~cm}$; number of branches per plant showed 3 to 6.66 range; number of cluster per plant ranged from 3 to 8 ; number of pods per cluster ranged from 2.66 to 5 ; number of pods per plant ranged between 6.66 to 35.33 ; pod length had 5.33 to $10 \mathrm{~cm}$ range; number of seeds per pod ranged from 6.33 to 10.66 ; hundred seed weight ranged from 3.12 to 4.98 $\mathrm{g}$ and seed yield per plant ranged between 1.51 to $12.03 \mathrm{~g}$ were presented in Table 2 .

\section{Phenotypic coefficient of variation (PCV) and genotypic coefficient of variation (GCV)}

When variation has to be compared for different characters each denoted by different units, using variance, standard deviation or standard error is not an acceptable measure. To overcome this challenge, coefficient of variation can be used. This unit less measure of variation is derived from both standard deviation and mean. Hence phenotypic and genotypic coefficients of variations are actual measures to compare the variation created for diverse characters.

In the present investigation, among eleven characters studied in breeding lines derived from fourteen crosses, the phenotypic and genotypic coefficient of variations were recorded high for the characters viz., number of pods per plant $(32.09 \%$ and $30.92 \%$ respectively) and seed yield per plant (36.61 $\%$ and $31.89 \%$ respectively) indicating that these characters were less affected by environment and these characters specify wider variability and vice versa.

The moderate phenotypic and genotypic coefficient of variation was recorded for the characters namely plant height $(14.01 \%$ and $13.49 \%$ respectively), number of branches per plant (17.86 \% and $14.33 \%$ respectively), number of clusters per plant $(19.03 \%$ and $14.47 \%$ respectively), number of pods per cluster (14.64 \% and $13.25 \%$ respectively) and hundred seed weight (15.08\% and 13.57 $\%$ respectively) (Table 2).Similar findings for number of pods per plant and seed yield per plant were reported by Patel et al., (2012); 
Hemavathy et al., (2015) and Bhutia et al., (2016). These traits are possibly to allow reasonable scope of improvement through selection in advanced generation due to their existence of comparatively moderate variability in green gram progeny lines evaluated.

In all the eleven studied characters in breeding lines of hybridized populations, phenotypic coefficient of variation was higher than genotypic coefficient of variation. This suggests that, environment has certain extent of influence on all these characters and the extent up to which it is influenced is estimated using heritability parameters.

\section{Heritability and genetic advance}

Heritability does differ among environments because environmental variance $\left(\mathrm{V}_{\mathrm{E}}\right)$ is a part of phenotypic variance $\left(\mathrm{V}_{\mathrm{P}}\right)$. Heritability is dimensionless therefore it is useful for comparing across species and traits that are measured on very different scales. Heritability and genetic advance can be used in these situations.

To design an effective selection strategy for the utilization of the existing breeding materials, the knowledge on the extent of variation, heritability of the trait and genetic gain is important (Azam et al., 2018).

In the present investigation heritability and the genetic advance under per cent of mean were observed to be high for the quantitative characters viz., plant height (92.72 and 26.76 $\%$ respectively), number of branches per plant (64.39 and $23.68 \%$ respectively), number of pods per cluster (81.85 and $24.69 \%$ respectively), number of pods per plant ( 92.86 and $61.38 \%$ respectively), hundred seed weight (80.98 and $25.16 \%$ respectively) and seed yield per plant (75.84 and 57.21\% respectively).
High heritability with moderate genetic advance under per cent of mean was recorded for pod length $(86.50$ and $13.85 \%$ respectively) and number of seeds per pod (90.62 and $13.69 \%$ respectively). Moderate heritability with high genetic advance under per cent of mean was recorded for the character number of clusters per plant $(57.80$ and $22.66 \%$ respectively) (Table 2 ).

These results are in conformity with the findings of Patel et al., (2012) for number of branches per plant, number of pods per plant and seed yield per plant and similar results were obtained by Hemavathy et al., (2015); Bhutia et al., (2016) and Prasad and Prasad, (2013) for plant height, number of pods per plant and hundred seed weight.

These characters are amenable for improvement by selection, particularly mass selection. Such value of high heritability and genetic gain may be attributed to additive effect. Hence, selection in segregating generations would be very effective for this character.

\section{Correlation and path analysis}

Correlation study has been conducted to identify the nature and extent of association between yield and its determinants. Selection for specific characters is known to result in correlated response in certain other characters (Falconer, 1960). Generally, plant breeders make selection for one or two attributes at a time and then it becomes important to know the effect on other characters. Path analysis allows the correlation coefficient to be broken down into direct and indirect effects on a dependent variable. Path coefficient analysis explains whether the association of seed yield per plant with its component characters is due to the direct effects of component characters on seed yield or is a consequence of its indirect effects through some other traits. 
Table.1 ANOVA for yield and yield attributing traits of green gram breeding lines

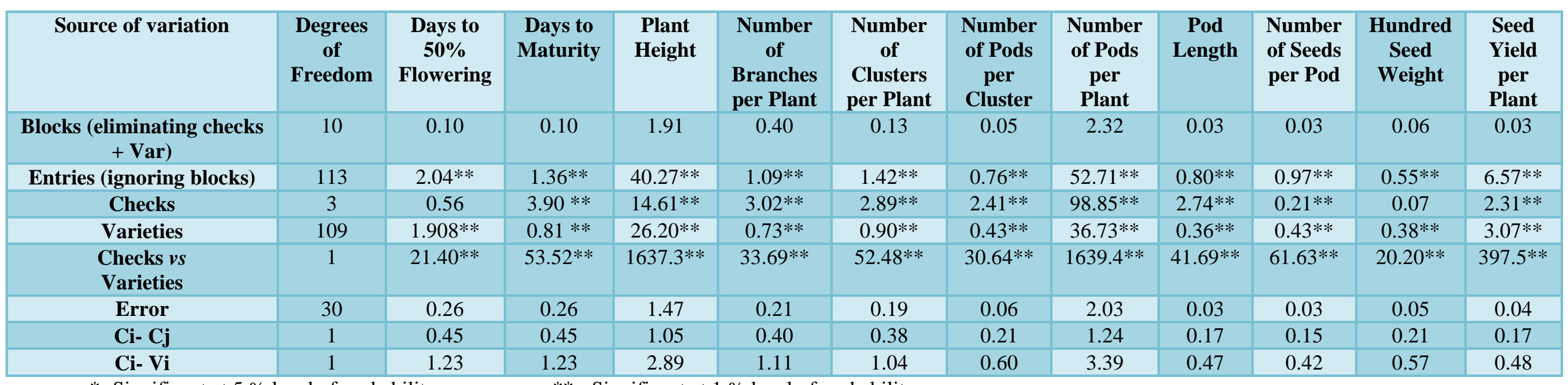

*-Significant at $5 \%$ level of probability $\quad * *$ - Significant at $1 \%$ level of probability

Table.2 Assessment of variability, heritability and genetic advance for yield and yield component traits

\begin{tabular}{|c|c|c|c|c|c|c|c|c|c|}
\hline \multirow{2}{*}{$\begin{array}{l}\text { Sl. } \\
\text { No }\end{array}$} & \multirow[t]{2}{*}{ Characters } & \multirow[t]{2}{*}{ Mean } & \multicolumn{2}{|c|}{ Range } & \multirow{2}{*}{$\begin{array}{c}\text { Genotypic } \\
\text { Coefficient of } \\
\text { Variation }(\%)\end{array}$} & \multirow{2}{*}{$\begin{array}{c}\text { Phenotypic } \\
\text { Coefficient of } \\
\text { Variation (\%) }\end{array}$} & \multirow{2}{*}{$\begin{array}{c}\text { Heritability } \\
\text { (broad sense) }(\%)\end{array}$} & \multirow{2}{*}{$\begin{array}{l}\text { Genetic } \\
\text { Advance }\end{array}$} & \multirow{2}{*}{$\begin{array}{l}\text { Genetic Advance } \\
\text { under Mean (\%) }\end{array}$} \\
\hline & & & MIN & MAX & & & & & \\
\hline 1 & Days to $50 \%$ flowering & 43.07 & 40.00 & 46.00 & 2.63 & 2.90 & 82.28 & 2.08 & 4.92 \\
\hline 2 & Days to maturity & 73.28 & 72.00 & 75.00 & 0.77 & 0.99 & 60.79 & 1.03 & 1.25 \\
\hline 3 & Plant height (cm) & 33.38 & 18.33 & 43.66 & 13.49 & 14.01 & 92.72 & 8.60 & 26.76 \\
\hline 4 & $\begin{array}{l}\text { Number of branches per } \\
\text { plant }\end{array}$ & 4.30 & 3.00 & 6.66 & 14.33 & 17.86 & 64.39 & 1.03 & 23.68 \\
\hline 5 & $\begin{array}{l}\text { Number of clusters per } \\
\text { plant }\end{array}$ & 4.85 & 3.00 & 8.00 & 14.47 & 19.03 & 57.80 & 1.04 & 22.66 \\
\hline 6 & $\begin{array}{l}\text { Number of pods per } \\
\text { cluster }\end{array}$ & 3.97 & 2.66 & 5.00 & 13.25 & 14.64 & 81.85 & 0.99 & 24.69 \\
\hline 7 & $\begin{array}{l}\text { Number of pods per } \\
\text { plant }\end{array}$ & 18.30 & 6.66 & 35.33 & 30.92 & 32.09 & 92.86 & 10.19 & 61.38 \\
\hline 8 & Pod length (cm) & 7.43 & 5.33 & 10.00 & 7.23 & 7.77 & 86.50 & 0.95 & 13.85 \\
\hline 9 & Number of seeds per pod & 8.41 & 6.33 & 10.66 & 6.98 & 7.33 & 90.62 & 1.08 & 13.69 \\
\hline 10 & Hundred seed weight (g) & 4.25 & 3.12 & 4.98 & 13.57 & 15.08 & 80.98 & 0.92 & 25.16 \\
\hline 11 & Seed yield per plant (g) & 5.53 & 1.51 & 12.03 & 31.89 & 36.61 & 75.84 & 2.46 & 57.21 \\
\hline
\end{tabular}


Table.3 Phenotypic correlation for yield and yield attributing traits in breeding lines of green gram

\begin{tabular}{|c|c|c|c|c|c|c|c|c|c|c|c|}
\hline Yield attributing traits & $\begin{array}{l}\text { Days to 50\% } \\
\text { Flowering }\end{array}$ & $\begin{array}{l}\text { Days to } \\
\text { Maturity }\end{array}$ & $\begin{array}{l}\text { Plant } \\
\text { Height }\end{array}$ & $\begin{array}{c}\text { Number of } \\
\text { Branches per } \\
\text { Plant }\end{array}$ & $\begin{array}{c}\text { Number of } \\
\text { Clusters per } \\
\text { Plant }\end{array}$ & $\begin{array}{l}\text { Number of } \\
\text { Pods per } \\
\text { Cluster }\end{array}$ & $\begin{array}{l}\text { Number of } \\
\text { Pods per } \\
\text { Plant }\end{array}$ & $\begin{array}{l}\text { Pod } \\
\text { Length }\end{array}$ & $\begin{array}{l}\text { Number of } \\
\text { Seeds per } \\
\text { Pod }\end{array}$ & $\begin{array}{l}\text { Hundred } \\
\text { Seed Weight }\end{array}$ & $\begin{array}{c}\text { Seed Yield } \\
\text { per Plant }\end{array}$ \\
\hline Days to $50 \%$ Flowering & 1 & $0.7846 * *$ & $0.4156^{* *}$ & $0.3410^{* *}$ & $0.4140 * *$ & $0.4206^{* *}$ & $0.3697 * *$ & -0.0362 & -0.0098 & $0.2518 * *$ & $0.2836^{* * *}$ \\
\hline Days to Maturity & & 1 & $0.3651^{* *}$ & $0.3364 * *$ & $0.3497 * *$ & $0.2937 * *$ & $0.3043 * *$ & 0.1551 & 0.1366 & $0.2459 * *$ & $0.2691 * *$ \\
\hline Plant Height & & & 1 & $0.7691 * *$ & $0.7076 * *$ & $0.5715^{* *}$ & $0.7190 * *$ & $0.2632 * *$ & $0.1950 *$ & $0.5726 * *$ & $0.6423^{* *}$ \\
\hline $\begin{array}{c}\text { Number of Branches } \\
\text { per Plant }\end{array}$ & & & & 1 & $0.8678 * *$ & $0.6147 * *$ & $0.7921 * *$ & $0.3180 * *$ & $0.2587 * *$ & $0.7076 * *$ & $0.7544 * *$ \\
\hline $\begin{array}{c}\text { Number of Clusters per } \\
\text { Plant }\end{array}$ & & & & & 1 & $0.6320 * *$ & $0.8441 * *$ & $0.3757 * *$ & $0.3551 * *$ & $0.6861 * *$ & $0.7532 * *$ \\
\hline $\begin{array}{c}\text { Number of Pods per } \\
\text { Cluster }\end{array}$ & & & & & & 1 & $0.7844 * *$ & $0.2918 * *$ & $0.2242 * *$ & $0.5939 * *$ & $0.6812 * *$ \\
\hline $\begin{array}{c}\text { Number of Pods per } \\
\text { Plant }\end{array}$ & & & & & & & 1 & $0.3419 * *$ & $0.3121 * *$ & $0.7800 * *$ & $0.8608 * *$ \\
\hline Pod Length & & & & & & & & 1 & $0.7864 * *$ & $0.2682^{* *}$ & $0.3187 * *$ \\
\hline $\begin{array}{c}\text { Number of Seeds per } \\
\text { Pod }\end{array}$ & & & & & & & & & 1 & $0.2476^{* *}$ & $0.2974 * *$ \\
\hline Hundred Seed Weight & & & & & & & & & & 1 & $0.8266 * *$ \\
\hline
\end{tabular}

*- Significant at $5 \%$ level of probability

** - Significant at $1 \%$ level of probability

Table.4 Direct and indirect effect of yield attributing characters on seed yield

\begin{tabular}{|c|c|c|c|c|c|c|c|c|c|c|}
\hline $\begin{array}{c}\text { Yield } \\
\text { attributing } \\
\text { traits }\end{array}$ & $\begin{array}{l}\text { Days to } 50 \% \\
\text { Flowering }\end{array}$ & $\begin{array}{c}\text { Days to } \\
\text { Maturity }\end{array}$ & $\begin{array}{l}\text { Plant } \\
\text { Height }\end{array}$ & $\begin{array}{c}\text { Number of } \\
\text { Branches per } \\
\text { Plant }\end{array}$ & $\begin{array}{l}\text { Number of } \\
\text { Clusters per } \\
\text { Plant }\end{array}$ & $\begin{array}{l}\text { Number of } \\
\text { Pods per } \\
\text { Cluster }\end{array}$ & $\begin{array}{c}\text { Number of } \\
\text { Pods per Plant }\end{array}$ & $\begin{array}{c}\text { Pod } \\
\text { Length }\end{array}$ & $\begin{array}{c}\text { Number of } \\
\text { Seeds per Pod }\end{array}$ & $\begin{array}{c}\text { Hundred } \\
\text { Seed Weight }\end{array}$ \\
\hline Days to $50 \%$ Flowering & -0.0708 & -0.0555 & -0.0294 & -0.0241 & -0.0293 & -0.0298 & -0.0262 & 0.0026 & 0.0007 & -0.0178 \\
\hline Days to Maturity & 0.0324 & 0.0412 & 0.0151 & 0.0139 & 0.0144 & 0.0121 & 0.0125 & 0.0064 & 0.0056 & 0.0101 \\
\hline Plant Height & 0.0036 & 0.0032 & 0.0086 & 0.0066 & 0.0061 & 0.0049 & 0.0062 & 0.0023 & 0.0017 & 0.0049 \\
\hline $\begin{array}{c}\text { Number of Branches } \\
\text { per Plant }\end{array}$ & 0.0365 & 0.0360 & 0.0823 & 0.1070 & 0.0929 & 0.0658 & 0.0848 & 0.0340 & 0.0277 & 0.0757 \\
\hline $\begin{array}{c}\text { Number of Clusters per } \\
\text { Plant }\end{array}$ & -0.0030 & -0.0025 & -0.0051 & -0.0063 & -0.0072 & -0.0046 & -0.0061 & -0.0027 & -0.0026 & -0.0050 \\
\hline $\begin{array}{c}\text { Number of Pods per } \\
\text { Cluster }\end{array}$ & 0.0233 & 0.0163 & 0.0317 & 0.0340 & 0.0350 & 0.0554 & 0.0434 & 0.0162 & 0.0124 & 0.0329 \\
\hline $\begin{array}{c}\text { Number of Pods per } \\
\text { Plant }\end{array}$ & 0.1688 & 0.1389 & 0.3283 & 0.3617 & 0.3854 & 0.3581 & 0.4566 & 0.1561 & 0.1421 & 0.3561 \\
\hline Pod Length & 0.0009 & -0.0038 & -0.0065 & -0.0078 & -0.0093 & -0.0072 & -0.0084 & -0.0247 & -0.0194 & -0.0066 \\
\hline $\begin{array}{c}\text { Number of Seeds per } \\
\text { Pod }\end{array}$ & -0.0004 & 0.0052 & 0.0075 & 0.0099 & 0.0136 & 0.0086 & 0.0120 & 0.0302 & 0.0384 & 0.0095 \\
\hline Hundred Seed Weight & 0.0923 & 0.0902 & 0.2100 & 0.2595 & 0.2516 & 0.2178 & 0.2860 & 0.0983 & 0.0908 & 0.3667 \\
\hline (r)Seed Yield per Plant & $0.2836 * *$ & $0.2691 * *$ & $0.6423 * *$ & $0.7544 * *$ & $0.7532 * *$ & $0.6812 * *$ & $0.8608^{* * *}$ & $0.3187 * *$ & $0.2974 * *$ & $0.8266 * *$ \\
\hline
\end{tabular}

Residual effect $=0.4367$ 
In the present investigation, the characters number of pods per plant and hundred seed weight had highest positive direct effect (0.4566 and 0.3667 respectively) (Table 4) and also had high positive correlation $(0.8608 * *$ and $0.8266 * *$ respectively) (Table 3 ) with seed yield. These findings are in accordance with the findings of Hemavathy et al., (2015); Patel et al., (2012) and Baisakh et al., (2016). Thus these are the most important and reliable characters and it can be utilized in direct selection for improving the seed yield. These characters had highest positive direct effect and relatively high positive indirect effect through other characters. Hence these characters can be used for improving seed yield.

The path diagram revealed a residual effect of 0.4367 indicates studied characters contribute 56.33 per cent to the yield. Relatively similar residual effects of $0.241,0.383$ and 0.375 were recorded by Hemavathy et al., (2015); Baisakh et al., (2016) and Anand et al., (2016). It can be concluded that, number of pods per plant and hundred seed weight should be given topmost priority while formulating a selection strategy for improvement of yield in green gram.

\section{Acknowledgment}

The authors are thankful to MULLaRP scheme, UAS, Dharwad for providing land and fund for conducting the field experiment. The authors also like to thank Dr. O Sridevi, professor of Genetics and Plant Breeding, UAS, Dharwad and Dr. Subhash B Kandakoor, Asst. professor of Agricultural Entomology, UAS, Dharwad for being a part of advisory committee.

\section{References}

Anand, G., K. Anandhi and Paulpandi, V. K. 2016.Genetic variability, correlation and path analysis for yield and yield components in $\mathrm{F}_{6}$ families of greengram [Vigna radiata (L.) Wilczek] under rainfed condition.Electronic Journal of Plant Breeding. 7(2): 15-17.

Azam, M. G., Hossain, M. A., Alam, M. S., Rahman, K. S., and Hossain, M. 2018. Genetic variability, heritability and correlation path analysis in mungbean [Vigna radiata $(\mathrm{L}$.$) Wilczek].$ Bangladesh Journal of Agricultural Research. 43(3): 407-416.

Baisakh, B., Swain, S.C., Panigrahi, K. K., Das, T.R., and Mohanty, A. 2016. Estimation of genetic variability and character association in micro mutant lines of greengram [Vigna radiata (L.) Wilczek] for Yield Attributes and Cold Tolerance. Legume Genomics and Genetics. 7(2): 01-09.

Bhutia, P., Lal, G. M., and Thomas, N. 2016.Studies on genetic variability, correlation and path analysis in greengram [Vigna radiata (L.)Wilczek] germplasm. International Journal of Agriculture Sciences. 2267- 2272.

Burton, G. W., and De Vane, E. M. 1953. Estimating heritability in tall fescue (Festuca arundinaceae) from replicated clonal material. Agronomy Journal. 51: 515-518.

Deway, D. R., and Lu, K. H. 1959. A correlation and path coefficient analysis of components of crested wheat grass seed production. Agronomy Journal. 51: 515-518.

Falconer, D. S., 1960. Introduction to quantitative genetics. oliver and bond ltd., tweeddale court, Bdinburgh I 39a welback street, London. pp. 161-304.

Hanson, G. H., Robinson, H. F., and Comstock, R. E. 1956. Biometrical studies of yeld in segregating populations of KorenLependeza. Agronomy Journal. 48(1): 267-282.

Hemavathy, A. T., Shunmugavalli, N., and Anand, G. 2015. Genetic variability, 
correlation and path co-efficient studies on yield and its components in mungbean [Vigna radiata (L.) Wilezek]. Legume Research. 38(4): 442-44.

Jhonson, H. W., Robinson, H. I., and Comstock, R. E. 1955.Estimation of genetic and environmental variability in soybean. Agronomy Journal. 47(12): 314-318.

Kumar, K., Prasad, Y., Mishra, S. B., Pandey, S. S., and Kumar, R. 2013. Study on genetic variability, correlation and path analysis with grain yield and yield attributing traits in green gram [Vigna radiata (L.) Wilczek]. Indian Journal of Agricultural Sciences. 8(4): 1551-1555.

Lush, J. L. 1949. Heritability of quantitative characters in farm animals. Hereditas. 35(S1): 356-375.

Patel, A. I., Mali, S. C., Intwala, C. G., and Nizama, J. R. 2012. Genetic variability, correlation, path analysis and genetic divergence in greengram [Vigna radiata (L.)Wilczek].Crop Research. 43(1): 178-184.

Prasad, B. V. V., and Prasad, G. S. 2013. Genetic variability, trait association and path analysis of yield and yield components in [Vigna radiata (L.) Wilczek]. International Journal of Bio-resource and Stress Management. 4(2): 251-254.

Sahu, H., Amadabade, J., Kumar, P., Sao, A., and Patel, R. K. 2015.Assessment of segregating generations for genetic variability and yield regulating traits in mungbean. The Biosean. 9(4): 1701-1706.

Singh, R. K., and Chaudhary, B. D. 1977.Biometrical method in quantitative genetics analysis. Kalyani Publishers, New Delhi.

Vavilov, N. I. 1926.The origin, variation, immunity and breeding of cultivated plants. Chronica Botonica. 13(1): 01364.

\section{How to cite this article:}

Abhisheka, L. S. and Suma C. Mogali. 2020. Genetic Variability, Correlation and Path coefficient Analysis for Yield and Yield Attributing Traits in Advanced Breeding Lines (ABLs) of Green Gram [Vigna radiata (L.)Wilczek] in $\mathrm{F}_{6}$ Generation. Int.J.Curr.Microbiol.App.Sci. 9(06): 314-321. doi: https://doi.org/10.20546/ijcmas.2020.906.041 